\title{
Efektivitas Pelatihan Anti-Bullying terhadap Pengetahuan Penanganan Kasus Bullying di Sekolah pada Guru-Guru TK Jakarta
}

\author{
Aliah B. Purwakania Hasan, Masni Erika Firmiana, \\ Emmalia Sutiasamita, Siti Rahmawati \\ Program Studi Psikologi, Fakultas Psikologi dan Pendidikan \\ Universitas Al Azhar Indonesia, Jl. Sisingamangaraja, Jakarta 12110 \\ Penulis untuk Korespondensi/E-mail: aliah@uai.ac.id
}

\begin{abstract}
Abstrak - Masalah school bullying, atau tindakan kekerasan berulang yang bersifat penghinaan pada korban yang merasa tidak berdaya di sekolah, terlihat terjadi di berbagai belahan dunia dengan frekuensi yang semakin meningkat. Penelitian ini bertujuan untuk mengembangkan modul dan pelatihan anti bullying di sekolah, dengan melihat efektivitas pelatihan tersebut di lingkungan guru-guru TK di Jakarta. Untuk mengembangkan modul pelatihan, dilakukan analisis kebutuhan pada 6 orang informan. Untuk melihat efektivitas pelatihan anti bullying dilakukan penelitian yang menggunakan eksperimen semu, dengan rancangan satu kelompok dengan pre dan post test. Sampling dilakukan secara insidental, dengan subjek yang mengikuti pelatihan sejumlah 32 orang. Hasil uji t-test menunjukkan terdapat perbedaan pengetahuan peserta tentang penanganan kasus bullying antara sebelum dan sesudah pelatihan $(t=2,723$; $\alpha=0,05)$. Dengan demikian, pelatihan yang meliputi karakteristik bullying, sistem pelaporan, deteksi dini dan sistem penangan di sekolah, masih perlu dikembangkan.
\end{abstract}

Abstract - The school bullying, or recurrent acts of violence contempt for the victims who feel helpless at school, was happening in increasing frequency on many parts of the world. This study aims to develop at school anti bullying modules and training, by looking at the effectiveness of the training on kindergarten teachers in Jakarta. Need analysis were conducted involving six informants to develop training modules. This research was using quasi- experimental method with one group pre and post test design to see the effectiveness of anti- bullying training. Incidental sampling was performed, with total of 32 subjects who following the training. This experiment $t$-test result showed significance differences on participants knowledge of how to handle bullying cases before and after training $(\mathrm{t}=2,723 ; \alpha=0.05)$. Therefore, the training covers the characteristics of bullying, reporting systems, early detection and management in school system of school bullying, still needs to be continously develop.

Keywords : School bullying, applied psychology, developmental psychology, mental health

\section{PENDAHULUAN}

$B$ ullying merupakan suatu masalah sosial yang telah ditemukan sejak usia sekolah, bahkan pada masa taman kanak-kanak. Penelitian Nansel dkk [1] terhadap 15.600 siswa grade 6 sampai 10 di Amerika Serikat menunjukkan bahwa sekitar $17 \%$ dari mereka telah menjadi korban bullying dengan frekuensi kadang-kadang dan sering selama masa sekolah, 19\% mengaku melakukan bullying pada orang lain dengan frekuensi kadangkadang dan sering, dan 6\% dari seluruh sampel menjadi pelaku dan korban bullying, dalam American Medical Association. [2]. Penelitian yang dilakukan Wang dkk terhadap 7.508 remaja di Amerika untuk menguji bentuk-bentuk perilaku school bullying pada remaja Amerika menunjukkan bahwa remaja yang menjadi korban bullying paling tidak sekali dalam dua bulan terakhir sebesar $20,8 \%$, telah mengalami bullying secara fisik, 53,6\% secara verbal, 51,4\% secara sosial, dan $13,6 \%$ melalui elektronik [3]. 
Sementara di Indonesia, Komisi Perlindungan Anak menyatakan bahwa tahun lalu setidaknya terdapat 2,339 kasus kekerasan fisik, psikologis dan seksual terhadap anak, dimana 300 di antaranya adalah kasus bullying. Krahe bahkan menyatakan bahwa hampir setiap anak dan remaja mungkin pernah mengalami suatu bentuk perlakuan tidak menyenangkan dari anak lain yang lebih tua atau lebih kuat [4]. Namun perlu disadari bahwa, kebanyakan perilaku bullying terjadi secara tersembunyi (covert) dan sering tidak dilaporkan sehingga kurang disadari oleh kebanyakan orang [5].

Bullying menurut Olweus adalah suatu perilaku negatif berulang yang bermaksud menyebabkan ketidaksenangan atau menyakitkan yang dilakukan oleh orang lain oleh satu atau beberapa orang secara langsung terhadap seseorang yang tidak mampu melawannya [6]. Olweus merumuskan adanya tiga unsur dasar bullying, yaitu bersifat menyerang dan negatif, dilakukan secara berulang kali, dan adanya ketidakseimbangan kekuatan antara pihak yang terlibat, dalam American Medical Association [2]. Coloroso juga mengatakan bahwa bullying akan selalu mengandung tiga elemen, yaitu: kekuatan yang tidak seimbang, bertujuan untuk menyakiti, dan ancaman akan dilakukannya agresi [7]. Sehingga seseorang dianggap menjadi korban bullying bila dihadapkan pada tindakan negatif seseorang atau lebih yang dilakukan berulang-ulang dan terjadi dari waktu ke waktu. Selain itu, bullying juga melibatkan kekuatan dan kekuasaan yang tidak seimbang, sehingga korbannya berada dalam keadaan tidak mampu mempertahankan diri secara efektif untuk melawan tindakan negatif yang diterimanya [4].

Dari berbagai penelitian diketahui bahwa bullying menimbulkan berbagai dampak negatif dan dengan tingkat keparahan yang bervariasi. Bagi korban bullying, sekolah dapat menjadi tempat yang tidak menyenangkan dan berbahaya. Ketakutan yang mereka alami dapat menimbulkan depresi, harga diri rendah, dan sering absen [5]. Penelitian lainnya dilakukan untuk menguji hubungan antara bullying, depresi, dan suicidal ideation terhadap 16.410 remaja (berusia 14-16 tahun) di Finlandia. Hasilnya menunjukkan sekitar 915 siswi dan 508 siswa diklasifikasikan mengalami depresi tingkat sedang hingga berat [8]. Kelompok bully-victim mengalami tingkat depresi yang lebih tinggi daripada kelompok victim dan bully. Kelompok subjek bullies yang cenderung mendominasi orang lain mungkin tidak merasakan tekanan ataupun celaan yang lebih rentan pada kelompok perempuan dan kelompok victim dan bully-victim [9]. Depresi pada anak-anak dan remaja diasosiasikan dengan meningkatnya perilaku bunuh diri [10]. Hal ini juga tampak dari beberapa kasus bunuh diri yang dialami remaja korban bullying di Indonesia.

Penelitian Hazler menunjukkan hanya sedikit guru yang mengenali kejadian atau mengidentifikasikan adanya bullying [11]. Hal ini konsisten dengan penelitian lain yang menunjukkan bahwa guruguru sering kali over-estimate efektivitas mereka dalam mengenali dan mengintervensi situasi bullying, terlepas dari berbagai jenis bullying yang terjadi [12]. Misalnya, dalam suatu penelitian, $70 \%$ guru-guru menyatakan bahwa mereka "hampir selalu" mengintervensi situasi bullying, sementara hanya $25 \%$ dari murid-murid mereka setuju dengan penelitian ini [13]. Suatu penelitian observasional menemukan bahwa guru-guru hanya melaporkan $18 \%$ insiden bullying yang terjadi di sekolah menengah dan sekolah dasar mereka [14]. Penelitian observasional lain di sekolah taman kanak-kanak menunjukkan bahwa guru-guru hanya mengintervensi $4 \%$ angka kejadian bullying [15]. Terlihat bahwa guru-guru bertindak tidak konsisten dalam mengintervensi bullying. Temuan ini mengindentifikasikan bahwa guru-guru tidak waspada terhadap bullying yang terjadi di sekolah, baik karena sulit dideteksi atau karena kurang dilaporkan oleh para siswa [12].

Penjelasan lain mengapa guru-guru terlihat kurang efektif dalam menangani situasi bullying, adalah sikap mereka terhadap bullying itu sendiri, khususnya dalam menghadapi berbagai jenis agresi. Misalnya, guru-guru cenderung mengatakan segala konflik fisik sebagai bullying, meskipun tidak terdapat perbedaan kekuasaan antara orang-orang yang terlibat [11]. Hal ini konsisten dengan penelitian yang mengindikasikan bahwa guru dan orang tua melihat agresi fisik lebih serius dan membutuhkan intervensi langsung dibandingkan bentuk lain dari agresi [16]. Lebih lanjut, Hazler mengatakan bahwa guru-guru sedikit kurang memperhatikan bentuk agresi lain yang merugikan sosial dan emosional dibandingkan konflik fisik [17].

Saat ini kasus-kasus perilaku bullying telah terjadi mulai dari usia taman kanak-kanak. Padahal masa ini penting sebagai dasar perkembangan selanjutnya.Usia dini adalah usia paling tepat 
untuk meletakkan dasar-dasar nilai kehidupan selanjutnya. Myers menyatakan semua pihak perlu memberikan perhatian lebih besar kepada potensi pengembangan kehidupan sosial dan emosi anak usia dini, demi kehidupannya di masa dewasa nanti [18]. Kehidupan sosial dan emosi yang dimaksud termasuk berhubungan dengan orang lain, terutama sebaya. Namun anak tidak akan mampu dengan sendirinya tanpa stimuli dari orang lain termasuk gurunya di TK. Jika tidak diberikan penananam anti bulyying dari usia dini, dikuatirkan akan sangat berdampak buruk pada kehidupannya di masa nanti, karena sudah diketahui bahwa bulllying mempengaruhi psikis manusia untuk masa panjang, dan dapat membuat seseorang merasa terisolasi, depresi, bahkan ingin bunuh diri. Dari sisi pelaku, perbuatan ini dapat berlangsung terus menerus pada jenjang pendidikan lanjutan di masa yang akan datang, dan mempengaruhi anak-anak lainnya. Di lain pihak, guru-guru TK merupakan pihak yang diharapkan dapat mendidik murid-muridnya. Guru-guru TK mungkin kurang mendapatkan laporan atau informasi tentang terjadinya bullying di sekolahnya.

Manfaat praktis dari kegiatan ini adalah guru-guru mendapatkan bekal untuk menghadapi masalah bullying yang mungkin terjadi pada muridmuridnya. Hasil yang didapatkan dari kegiatan ini dapat digunakan sebagai bahan pertimbangan untuk pola pendidikan guru-guru dan orang tua terhadap anak dan dapat digunakan sebagai referensi dalam usaha meminimalisasi perilaku agresi pada anak mereka.

\section{KERANGKA TEORITIS}

Pada dasarnya perilaku agresi ini sudah dapat dikendalikan oleh bayi sejak mereka berusia sekitar tiga bulan. Pola-pola perilaku agresi yang ditampilkan oleh bayi yang berusia sekitar tiga bulan adalah dalam bentuk temper tantrum, yaitu luapan emosi yang kuat yang disertai kemarahan dan menangis sambil menghentak-hentakan kaki ke lantai. Perilaku ini belum merupakan tindakan bullying, yang baru timbul setelah anak memiliki hubungan sosial dengan teman-teman sebayanya. Seperti yang didefinisikan oleh Buss, secara umum dinyatakan bahwa perilaku agresi merupakan perilaku yang dapat merusak atau menyakiti orang lain [19]. Menurut Sarwono, ada tiga sumber dalam berkembangnya perilaku agresi, yaitu meniru pada keluarga atau modelling, lingkungan atau budaya dimana individu tinggal, dan media massa [20].

Huesman dkk. berpendapat bahwa pola asuh yang diterima anak dari orang tuanya juga dipercaya memberikan kontribusi dalam bentuk dan berkembangnya perilaku agresi anak [21]. Adanya orang tua sebagai model agresi memudahkan terciptanya perbendaharaan perilaku agresi pada anak. Agresi dan kebencian merupakan perilaku yang tidak dapat dihindari dari pengalaman masa anak-anak akibat pola asuh orang tuanya. Disinilah pola asuh orang tua berperan, bagaimana mereka membesarkan, mendidik, melindungi, memberi kasih sayang, bahkan sampai menjadi model yang baik bagi anak-anaknya. Hal terbaik dalam pola asuh adalah adanya keterlibatan interaksi dengan anak, orang tua, dan lingkungan [20]. Baumrind mengatakan ada tiga pendekatan atau pola asuh dalam interaksi orang tua dengan anak-anaknya dalam keluarga, seperti yaitu authoritarian, permissive, dan authoritative [22].

Orang tua yang authoritarian adalah orang tua yang menerapkan pola asuh yang sangat ketat terhadap anak-anaknya dan juga bersifat menghukum dan mengekang keinginan anak atau dengan kata lain segala aturan orang tua harus ditaati oleh anak. Selanjutnya menurut Turner, pola asuh authoritarian dapat membuat anak remaja menjadi pemberontak, suka melukai orang lain, dan menjadi sangat tergantung pada orang lain [23]. Anderson dkk. berpendapat bahwa ada hubungan menentang dan membangkang biasanya orang tuanya lebih authoritarian daripada yang penurut dan mudah diatur [21]. Perilaku agresi yang muncul pada anak diawali dengan adanya sikap tidak menurut dan membangkang pada orang tua. Anak yang diasuh dengan pola asuh authoritarian cenderung akan mengembangkan perilaku agresi.

Menurut Baumrind, pola asuh orang tua yang permissive adalah pola asuh orang tua yang bebas [22]. Orang tua tidak mendorong anaknya untuk mentaati norma atau peraturan yang berlaku. Orang tua memberikan kebebasan kepada anak remajanya untuk mengatur kegiatannya sendiri, dejauh mereka masih dapat melaksanakannya. Anak diajar untuk menanggung konsekuensi dari hasil perbuatannya sendiri. Dengan pola asuh yang seperti ini, maka seorang anak cenderung mengembangkan perilaku agresi yang terbuka atau terang-terangan. Sedangkan menurut Anderson, orang tua yang menerapka pola asuh permissive 
akan membuat anak menjadi sulit diatur, suka menentang dan membangkang terhadap orang tuanya bahkan orang dewasa lainnya [21]. Melalui pola asuh permissive ini anak belajar bahwa apa saja boleh dilakukan atau apa yang diperbuat adalah benar karena orang tua tidak pernah melarang apalagi menghukum. Sehingga pola asuh permissive berdampak negatif pada anak, yaitu anak menjadi tidak terbiasa untuk membedakan mana yang boleh dan mana yang tidak boleh dilakukan.

Menurut Turner, pola asuh authorotative adalah pola asuh yang memberikan kesempatan yang luas kepada anaknya untuk mengambil keputusan sendiri, namun orang tua tetap menguasai keputusan terakhir [23]. Pada pola asuh ini terdapat komunikasi yang baik serta sikap yang hangat dan terbuka antara orang tua dengan anaknya. Dalam mengarahkan tingkan laku anaknya orang tua tidak menekankan bahwa seseorang harus patuh dan tidak boleh menantang keinginan orang tuanya, tetapi dengan memberikan pengertian dan penjelasan yang dapat diterima oleh anak. Orang tua yang authoritative dapat menjadi model yang baik bagi anaknya. Koeswara, mengemukakan bahwa seorang anak atau individu yang menerima penanaman nilai-nilai atau dididik disiplin dengan pola asuh authoritative rata-rata tidak melakukan perilaku agresi [24]. Pola asuh authoritarian dan permissive dapat membuat seorang anak mengembangkan sikap sulit diatur, suka menentang, membangkang, dan menjadi pemberontak, sehingga pola asuh ini dapat membuat seorang anak menjadi agresif. Sedangkan anak yang menerima pola asuh secara authoritative tidak menunjukkan tanda-tanda perilaku agresi, hal tersebut dikarenakan adanya komunikasi yang terjalin sangat baik antara orang tua dengan anak.

Di samping itu urutan kelahiran juga turut mempengaruhi perilaku agresi pada anak-anaknya. Karena seperti yang sudah kita ketahui bahwa kebanyakan orang tua menerapkan pola asuh yang berbeda kepada anak-anaknya. Orang tua biasanya menerapkan pola asuh yang authoritarian kepada anak sulungnya, karena mereka berharap anak sulungnya dapat menjadi seorang anak yang dapat diandalkan dan dapat menjadi panutan untuk adikadiknya kelak. Sedangkan anak bungsu, orang tua lebih menerapkan pola asuh permissive, dimana segala keinginan anak selalu dituruti sehingga anak bungsu dikenal sebagai anak yang manja. Dengan penerapan pola asuh yang seperti ini secara tidak langsung sudah menumbuhkan perilaku agresi, karena anak sulung merasa tidak diperlakukan adil oleh orang tuanya. Selain itu perceraian orang tua dapat berdampak pada timbulnya perilaku agresi pada remaja.

Anak dengan orang tua bercerai cederung lebih agresi bila dibandingkan dengan remaja yang orang tuanya tidak bercerai [25]. Anak dengan orang tua yang bercerai cendeung lebih agresi karena mereka mencari perhatian dari orang tuanya, selain itu mereka merasa seperti anak yang dibuang oleh orang tuanya karena orang tuanya tidak memperdulikannya lagi, segala sesuatu yang menyangkut masalah anak diserahkan begitu saja tanpa ada pengawasan dari orang tua, sehingga tidak ada lagi komunkasi antara orang tua dengan anaknya. Berbeda dengan anak yang tinggal dengan orang tua yang tidak bercerai, anak dengan orang tua yang utuh perilaku agresinya cenderung terkontrol, karena mereka masih memiliki orang tua yang memperhatikan dan memberikan pengarahan kepada anaknya dalam melakukan segala kegiatannya, sehingga terjalin komunikasi yang baik antara orang tua dan anak. Padahal, tokoh yang paling utama dan paling berperan dalam kehidupan seorang anak pada umumnya adalah orang tua karena orang tua memiliki peran yang khusus dalam pendewasaan anaknya [25].

Perilaku agresi yang ditampilkan oleh anak lakilaki dan perempuan juga berbeda. Anak laki-laki pada umumnya memperlihatkan tingkat agresi fisik yang lebih tinggi daripada anak perempuan. Anak perempuan memperlihatkan agresi yang substansial dalam bentuk agresi verbal, seperti menyumpah dan name calling (memberi nama ejekan), maupun agresi relasional, seperti mengucilkan teman dan bergosip [26][27].

\section{METODE}

Melihat situasi yang berkembang saat ini, terlihat pentingnya pengembangan sumber daya manusia yang handal yang memenuhi standar kompetensi untuk mengembangkan program-program untuk menangani bullying. Model yang akan dipergunakan terdiri dari analisis kebutuhan, perancangan, pengembangan, implementasi dan evaluasi. 


\section{ADDIE Model of Design}

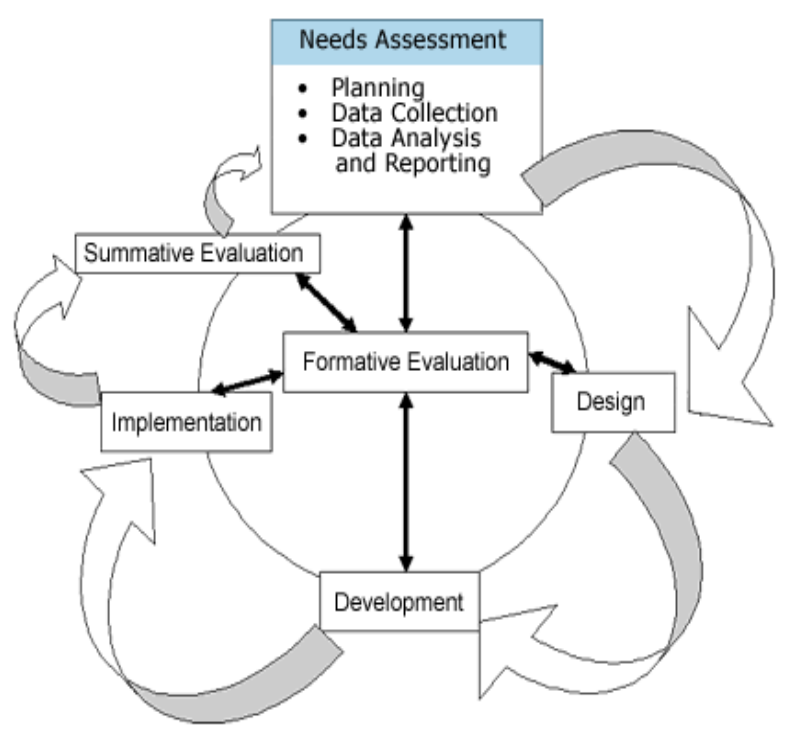

Gambar 1. Rancangan pemecahan masalah

Untuk melihat apakah modul ini dapat dipergunakan dalam penelitian yang bertujuan untuk melakukakn uji coba berupa pelatihan yang dengan sampel sebanyak 32 orang peserta, yang diambil dengan teknik sampling insidental. Penelitian ini menggunakan eksperimen semu dengan rancangan satu kelompok dengan pretes dan postes (one group pretest and posttest design). Pada masing-masing peserta diberikan ujian sebelum dan sesudah tes untuk melihat penyerapan terhadap materi yang diberikan. Teknik statistik yang dipergunakan adalah paired sample t-test. Selain itu, masing-masing peserta diminta untuk mengisi hasil evaluasi pelatihan untuk melihat bagaimana proses pelatihan yang dilakukan. Data hasil evaluasi dihitung dengan statistik deskriptif dengan melihat nilai rerata dari masing-masing butir.

\section{HASIL DAN ANALISIS HASIL}

Sebelum menyusun modul dan mencari bahan pustaka yang relevan, diadakan analisis kebutuhan pelatihan. Formulir analisis kebutuhan menanyakan penilaian apakah modul pelatihan untuk mencegah terjadinya bullying dibutuhkan, bagaimana mereka melihat masalah bullying di sekitar mereka, hal-hal apa saja yang dibutuhkan untuk menangani bullying, dan topik materi pelatihan apa menurut mereka yang dibutuhkan untuk menangani bullying. Daftar pertanyaan ini diberikan kepada 2 orang psikolog anak, 2 orang guru PAUD dan 2 orang tua yang memiliki anak yang sekolah di PAUD.

Seluruh informan penelitian ini menyatakan sangat pentingnya modul pelatihan untuk mencegah terjadinya bullying, walaupun masing-masing pihak melihatnya dari posisi yang berbeda-beda. Pada intinya, mereka melihat bahwa modul dapat dikembangkan sebagai upaya untuk mencegah terjadinya bullying, dan penting untuk melihat posisi masing-masing dalam pencegahan bullying, agar kerjasama dapat dilakukan dengan baik.

Dalam analisis kebutuhan, para informan menjelaskan tentang masalah yang mereka rasakan dalam menghadapi masalah bullying, berikut saran penanganan dan topik materi pelatihan yang dibutuhkan. Secara umum, masalah yang dirasakan meliputi terlambatnya identifikasi, perkembangan anak yang tidak optimal akibat terjadinya bullyilng, kurangnya kemampuan untuk menangani baik dari sisi korban maupun pelaku, hambatan untuk untuk menangani atau pelaporan kasus bullying baik dari sisi korban maupun saksi, keakuratan informasi tentang bullying, penanganan yang kurang tepat baik dari sisi individu maupun sistem, sikap dan cara menghadapi orang tua, tanggung jawab atau kerjasama bersama terutama antara guru dan orang tua supaya tidak saling menyalahkan, dan adanya anggapan bahwa bullying merupakan warisan budaya sekolah tertentu. 
Tabel 1. Gambaran analisis kebutuhan kepentingan pelatihan

\begin{tabular}{lll}
\hline \multicolumn{1}{c}{ Informan } & \multicolumn{1}{c}{$\begin{array}{c}\text { Tingkat } \\
\text { Kepentingan }\end{array}$} & \multicolumn{1}{c}{ Alasan } \\
\hline $\begin{array}{l}\text { K (psikolog, } \\
\text { perempuan, 45 } \\
\text { tahun) }\end{array}$ & Sangat penting & $\begin{array}{l}\text { Modul seperti ini merupakan upaya pencegahan yang penting } \\
\text { untuk mencegah terjadinya bullying di sekolah sejak dini. Semua } \\
\text { dapat aktif bekerja sama, agar hal seperti ini dapat ditangani } \\
\text { dengan cepat dan tepat. }\end{array}$ \\
\hline $\begin{array}{l}\text { A (psikolog, laki- } \\
\text { laki, 39 tahun) }\end{array}$ & Sangat penting & $\begin{array}{l}\text { Modul seperti ini penting, sebagai persiapan dan upaya } \\
\text { pencegahan dalam menghadapi masalah kritis anak, sehingga } \\
\text { perkembangan anak menjadi lebih optimal. }\end{array}$ \\
\hline $\begin{array}{l}\text { F (guru PAUD, } \\
\text { perempuan, 28 } \\
\text { tahun) }\end{array}$ & Sangat penting & $\begin{array}{l}\text { Pegangan seperti itu penting, mengingat tanggung jawab yang } \\
\text { berat yang dipikulkan kepada guru. Dengan demikian, semua } \\
\text { orang dapat bertanggung jawab sesuai dengan kapasitasnya. }\end{array}$ \\
\hline $\begin{array}{l}\text { S (guru PAUD, laki- } \\
\text { laki, 44 tahun) }\end{array}$ & Sangat penting & $\begin{array}{l}\text { Penting untuk berfokus mencari solusi, dan menghindari saling } \\
\text { menyalahkan yang justru memperkeruh suasana. }\end{array}$ \\
\hline $\begin{array}{l}\text { Yu (Orang tua, } \\
\text { perempuan, 33 tahun }\end{array}$ & Sangat penting & $\begin{array}{l}\text { Jika terjadi, hal ini sangat menakutkan, sehinggap apapun upaya } \\
\text { pencegahannya sangat penting, supaya tidak berlangsung terus } \\
\text { menerus. }\end{array}$ \\
\hline $\begin{array}{l}\text { W (Orang tua, laki- } \\
\text { laki, 35 tahun) }\end{array}$ & Sangat penting & $\begin{array}{l}\text { Peristiwa seperti ini harus dicegah sejak dini, perlu kejelasan } \\
\text { bagaimana guru dan orang tua dapat saling bekerja sama. }\end{array}$ \\
\hline
\end{tabular}

Tabel 2. Analisis kebutuhan masalah, penanganan dan topik materi pelatihan

\begin{tabular}{|c|c|c|c|}
\hline Informan & Masalah & Penanganan & Topik Materi Pelatihan \\
\hline $\begin{array}{l}\text { K (psikolog, } \\
\text { perempuan, } 45 \\
\text { tahun) }\end{array}$ & $\begin{array}{l}\text { Terlambatnya identifikasi, } \\
\text { kurangnya kemampuan } \\
\text { untuk menangani, } \\
\text { pentingnya kerjasama. }\end{array}$ & $\begin{array}{l}\text { Deteksi dini, penanganan } \\
\text { pelaku, korban dan saksi, baik } \\
\text { dari sisi individu dan sistem. }\end{array}$ & $\begin{array}{l}\text { Deteksi dini, penanganan } \\
\text { pelaku, korban dan saksi, } \\
\text { baik dari sisi individu dan } \\
\text { sistem. }\end{array}$ \\
\hline $\begin{array}{l}\text { A (psikolog, } \\
\text { laki-laki, } 39 \\
\text { tahun) }\end{array}$ & $\begin{array}{l}\text { Perkembangan anak tidak } \\
\text { optimal, hambatan untuk } \\
\text { mengenali adanya } \\
\text { masalah, penanganan } \\
\text { korban yang kurang tepat }\end{array}$ & $\begin{array}{l}\text { Deteksi dini, pelaporan } \\
\text { masalah, penanganan pelaku, } \\
\text { korban dan saksi, baik dari sisi } \\
\text { individu dan sistem. }\end{array}$ & $\begin{array}{l}\text { Dampak bullying pada } \\
\text { pelaku dan korban, deteksi } \\
\text { dini, penanganan pelaku, } \\
\text { korban dan saksi, baik dari } \\
\text { sisi individu dan sistem. }\end{array}$ \\
\hline $\begin{array}{l}\text { F (guru PAUD, } \\
\text { perempuan, } 28 \\
\text { tahun) }\end{array}$ & $\begin{array}{l}\text { Menghadapi murid dan } \\
\text { orang tua yang menjadi } \\
\text { pelaku dan korban, saksi } \\
\text { yang kurang untuk } \\
\text { memastikan apa yang } \\
\text { terjadi. }\end{array}$ & $\begin{array}{l}\text { Pelaporan pada orang tua, } \\
\text { penanganan pelaku, korban dan } \\
\text { saksi, baik dari sisi individu } \\
\text { dan sistem, mendorong saksi } \\
\text { untuk melapor. }\end{array}$ & $\begin{array}{l}\text { Sistem pelaporan pada orang } \\
\text { tua, penanganan pelaku, } \\
\text { korban dan saksi, baik dari } \\
\text { sisi individu dan sistem, } \\
\text { mendorong dan mengatasi } \\
\text { hambatan saksi untuk } \\
\text { melapor. }\end{array}$ \\
\hline $\begin{array}{l}\text { S (guru PAUD, } \\
\text { laki-laki, } 44 \\
\text { tahun) }\end{array}$ & $\begin{array}{l}\text { Mencari kambing hitam, } \\
\text { informasi yang tidak } \\
\text { akurat, upaya } \\
\text { penanggulangan yang } \\
\text { kurang tepat }\end{array}$ & $\begin{array}{l}\text { Kerjasama orang tua dan } \\
\text { pendidik, penanganan pelaku, } \\
\text { korban dan saksi, baik dari sisi } \\
\text { individu dan sistem. }\end{array}$ & $\begin{array}{l}\text { Kerjasama orang tua dan } \\
\text { pendidik, penanganan } \\
\text { pelaku, korban dan saksi, } \\
\text { baik dari sisi individu dan } \\
\text { sistem. }\end{array}$ \\
\hline $\begin{array}{l}\text { Yu (Orang tua, } \\
\text { perempuan, } 33 \\
\text { tahun }\end{array}$ & $\begin{array}{l}\text { Kemungkinan warisan } \\
\text { turun temurun, mencari } \\
\text { sekolah yang tidak ada } \\
\text { bullying baik di jalan } \\
\text { maupun lingkungan } \\
\text { sekolah. }\end{array}$ & $\begin{array}{l}\text { Memutus rantai bullying, } \\
\text { membentuk budaya sekolah } \\
\text { yang sehat }\end{array}$ & $\begin{array}{l}\text { Memutus rantai bullying. } \\
\text { budaya sekolah yang sehat. }\end{array}$ \\
\hline $\begin{array}{l}\text { W (Orang tua, } \\
\text { laki-laki, } 35 \\
\text { tahun) }\end{array}$ & $\begin{array}{l}\text { Tanggung jawab guru dan } \\
\text { orang tua, pencegahan dan } \\
\text { penanganan yang tepat. }\end{array}$ & $\begin{array}{l}\text { Kerjasama orang tua dan } \\
\text { pendidik, penanganan pelaku, } \\
\text { korban dan saksi, baik dari sisi } \\
\text { individu dan sistem. }\end{array}$ & $\begin{array}{l}\text { Kerjasama orang tua dan } \\
\text { pendidik, penanganan } \\
\text { pelaku, korban dan saksi, } \\
\text { baik dari sisi individu dan } \\
\text { sistem. }\end{array}$ \\
\hline
\end{tabular}


Dengan demikian, berdasarkan analisis kebutuhann penanganan dan topik yang dibuat dalam modul pelatihan ini meliputi pengertian dan batasan bullying, dampak bullying bagi perkembangan anak, deteksi dini masalah bullying di sekolah, mengatasi hambatan pelaporan masalah bullying, penangan kasus bullying baik dari individu maupun saksi, memutus rantai dengan sistem dan budaya sekolah yang komprehensif untuk mengatasi masalah bullying. Supaya lebih komprehensif, pembahasan diharapkan meliputi semua pihak yang terlibat, baik dari sisi penyintas, pelaku dan saksi.

Untuk melihat apakah modul ini dapat dipergunakan dalam pelatihan diadakan uji coba berupa pelatihan yang mengundang 32 orang peserta. Pada masing-masing peserta diberikan ujian sebelum dan sesudah tes untuk melihat penyerapan terhadap materi yang diberikan. Selain itu, masing-masing peserta diminta untuk mengisi hasil evaluasi pelatihan untuk melihat bagaimana proses pelatihan yang dilakukan.

Tabel 3. Gambaran deskriptif subjek penelitian

Paired Samples Statistics

\begin{tabular}{|c|c|c|c|c|c|}
\hline & & Mean & $\mathrm{N}$ & Std. Deviation & Std. Error Mean \\
\hline \multirow{2}{*}{ Pair 1} & postes & 11.0313 & 32 & 2.86789 & .50698 \\
\hline & pretes & 9.4375 & 32 & 3.65388 & .64592 \\
\hline
\end{tabular}

Tabel 4. Korelasi berpasangan subjek penelitian

Paired Samples Correlations

\begin{tabular}{|c|c|c|c|c|}
\hline & & $\mathrm{N}$ & Correlation & Sig. \\
\hline Pair 1 & postes \& pretes & 32 & .507 & .003 \\
\hline
\end{tabular}

Tabel 5. Hasil uji t-tes subjek penelitian

Paired Samples Test

\begin{tabular}{|c|c|c|c|c|c|c|c|c|}
\hline & \multicolumn{5}{|c|}{ Paired Differences } & \multirow[b]{3}{*}{$t$} & \multirow[b]{3}{*}{$d f$} & \multirow[b]{3}{*}{ Sig. (2-tailed) } \\
\hline & \multirow[b]{2}{*}{ Mean } & \multirow[b]{2}{*}{ Std. Deviation } & \multirow{2}{*}{$\begin{array}{l}\text { Std. Error } \\
\text { Mean }\end{array}$} & \multicolumn{2}{|c|}{$\begin{array}{l}\text { 95\% Confidence Interval of the } \\
\text { Difference }\end{array}$} & & & \\
\hline & & & & Lower & Upper & & & \\
\hline Pair 1 postes - pretes & 1.59375 & 3.31039 & .58520 & .40023 & 2.78727 & 2.723 & 31 & .011 \\
\hline
\end{tabular}

Hasil t-test menunjukkan terdapat perbedaan tingkat pengetahuan tentang penanganan bullying antara sebelum dan sesudah pelatihan, dengan $\mathrm{t}=2,723 \alpha=0,05$. Rerata nilai sebelum pelatihan adalah 9,4375 dan sesudah pelatihan sebesar 11,0313. Dengan demikian, pelatihan yang dilakukan memiliki efektivitas yang baik. Selain itu, hasil evaluasi pelatihan menunjukkan bahwa pelaksanaan pelatihan sendiri dianggap cukup memuaskan para pesertanya.

Saat pelatihan, modul diberikan kepada peserta untuk dapat diimplementasikan di sekolah masing- masing. Peserta diharapkan dapat menjadi fasillitator dan agen perubahan di tempat mereka bekerja. Masing-masing peserta diharapkan dapat menggunakan modul ini dalam pelatihan yang mereka buat di masa yang akan datang. Modul diberikan kepada peserta untuk dapat diimplementasikan di sekolah masing-masing. Peserta diharapkan dapat menjadi fasillitator dan agen perubahan di tempat mereka bekerja. Masingmasing peserta diharapkan dapat menggunakan modul ini dalam pelatihan yang mereka buat di masa yang akan datang. 


\section{KESIMPULAN}

Melalui penelitian ini telah dihasilkan modul untuk menangani masalah bullying. Modul ini meliputi pengertian dan batasan bullying, dampak bullying bagi perkembangan anak, deteksi dini, pelaporan dan penangan bullying baik dari individu maupun sistemik. Pembahasan modul meliputi sisi penyintas, pelaku dan saksi. Secara umum, modul yang telah dibuat dapat menjadi rujukan singkat untuk menangani kasus-kasus bullying yang terjadi.

\section{SARAN}

Untuk meningkatkan kualitas modul ini, masih dibutuhkan penyempurnaan lebih lanjut berdasarkan hasil evaluasi pelatihan. Dibutuhkan pula pelatihan lanjutan untuk membuat topik pembahasan dalam modul ini lebih dikenal dan lebih tersebar bagi pihak yang membutuhkan. Selain itu, dapat dibuat situs untuk menyebarkan modul melalui jaringan internet.

\section{DAFTAR PUSTAKA}

[1] Nansel, T.R., Overpeck, M., Pilla, R.S., Ruan, W.J., Simon-Morton, B., Scheidt, P. (2001) Bulllying behavior among US Youth: Prevalence and association with psychosocial adjustment. JAMA, April 25; 285 (10)-294 (100)

[2] American Medical Association. (2002). Educational forum on adolescent health: Youth bullying. May 2002. Chicago, Illinois.

[3] Wang, J., Iannoti, R.J., Nansel,T.R. (2009) School bullying among adolescents in the Uniited States: physical, verbal, relational and cyber. Journal of adolescents health. Oct 2009, 45 (4): 308-75

[4] Krahe, B. (2005). Perilaku Agresif. Buku panduan psikologi sosial. Yogyakarta: Pustaka Pelajar.

[5] Glew, Rivara, Feudtner. (2000). Bullying: children hurting children. Pediatrics in Review. Seattle: University of Washington.

[6] Olweus, D. (2006). Bullying at school: What we know and what we can do. New York: Blackwell.

[7] Coloroso, B. (2003). The bully, the bullied and the bystander. New York.

[8] Kaltiala-Hetno, R., Marttunen, R., Rantanen (1997). Bullying, deppression and suicidal ideation in Finnish adolescents: school survey. Finland: Chesson

[9] Sonia,V. (2009). Perbedaan depresi ditinjau dari segi bullying. Universitas Sumatera Utara: Fakultas Psikologi.

[10] Lubis, N.L. (2009). Depresi Tinjauan Psikologis. Jakarta: Prenada

[11] Hazler, R.J. Miler, Carney, Green. (2001). Adult recognition of school bullying situations. Educational research, 43(2), 133-146

[12] Limber, S.P. (2008). Cyber bullying in the digital age. New York: John Wiley \& Sons

[13] Charach, A., Pepler, D.J. (1995). Bullying at school. A Canadian perspectives. Educational Canada 35. 12-18

[14] Atlas, R., Pepler, D.J. (1998). Observation of bullying in the classroom. American journal of educational research, 92, 86-99.

[15] Craig, W.M., Pepler, D.J. (2000). Observations of bullying and victimization in the schoolyard. Canadian journal of school psychology, 2, 41-60.

[16] Bauman, S., Del Rio, A. (2006). Preservices teacher responses to bullying scenarios: Comparing physical, verbal and ralational bullying. Jounral of educational psychology, 98 (1), 219

[17] Hazler, R.J. (2001). Bullying: Counseling perperators and victims. New York: John Wiley \& Sons.

[18] Myer, R. (1995). The Twelve Who Survive. Strengthening Programmes of Early Childhood Development in the Third World. Michigan : High/Scope Press.

[19] Morgan, M. (1999). Hearing children voices. Qualitative research, April 2, 15-20

[20] Sarwono, S.W. (1999). Psikologi Sosial. Jakarta: Rajawali

[21] Anderson, C.A. (2001). Effects of violent video games on aggressive behavior. London: Sage Pub

[22] Berk, L.E. (1994). Child development. Needharm Height: Allyn \& Bacon.

[23] Turner, J,C. (1995). Child psychology. London: Sage Pub.

[24] Koeswara, E. (1988). Agresi manusia. Bandung: PT Erasco

[25] Hurlock, E. (1980). Psikologi Perkembangan. Jakarta: Erlangga

[26] Grotpeter, J.K., \& Crick, N.R. (1996). Relational aggression, overt aggression, and friendship. Child Development, 67, 2328-2338.

[27] Rys, G.S., \& Bear, G.G. (1997). Relational aggression and peer relations: Gender and developmental issues. Merrill-Palmer Quarterly, $43,87-106$ 